\title{
Nonomuraea jiangxiensis sp. nov., isolated from acidic soil
}

\author{
Xiaomin Li, ${ }^{1,2}$ Limin Zhang, ${ }^{1}$ Yun Ding, ${ }^{1,2}$ Yongsheng Gao, ${ }^{2}$ \\ Jisheng Ruan ${ }^{1}$ and Ying Huang ${ }^{1}$ \\ ${ }^{1}$ State Key Laboratory of Microbial Resources, Institute of Microbiology, Chinese Academy of \\ Sciences, Beijing 100101, PR China \\ ${ }^{2}$ College of Land Resources and Environment, Jiangxi Agricultural University, Nanchang 330045, \\ Jiangxi Province, PR China
}

Correspondence Ying Huang huangy@im.ac.cn

\begin{abstract}
An actinomycete, designated $\mathrm{FXJ} 1.102^{\top}$, was isolated from acidic soil collected in Jiangxi Province, south-east China. Phylogenetic analysis based on 16S rRNA gene sequences indicated that strain FXJ1.102 ${ }^{\top}$ belonged to the genus Nonomuraea and was most closely related to Nonomuraea candida $\mathrm{HMC10} 0^{\top}$, Nonomuraea turkmeniaca DSM 43926 ${ }^{\top}$, Nonomuraea antimicrobica YIM $61105^{\top}$ and 'Nonomuraea aegyptia' S136 (98.9, 98.3, 97.9 and 97.5\% 16S rRNA gene sequence similarities, respectively). The morphological characteristics were typical of the genus Nonomuraea. The chemotaxonomic properties, such as cell-wall chemotype IIIB, phospholipid type IV, MK-9 $\left(\mathrm{H}_{4}\right)$ as the major menaquinone and iso- $\mathrm{C}_{16: 0}(22.2 \%)$ as the major fatty acid, supported the assignment of the strain to the genus Nonomuraea. DNA-DNA relatedness and physiological tests allowed genotypic and phenotypic differentiation of strain FXJ1.102 ${ }^{\top}$ from its closest phylogenetic relatives. The isolate therefore represents a novel species, for which the name Nonomuraea jiangxiensis sp. nov. is proposed. The type strain is FXJ1.102 $2^{\top}\left(=\right.$ CGMCC $4.6533^{\top}=$ NBRC $\left.106679^{\top}\right)$.
\end{abstract}

The genus Nonomuraea, the spelling of which was corrected by Chiba et al. (1999), was originally proposed by Zhang et al. (1998) as a member of the family Streptosporangiaceae, which forms extensively branched substrate and aerial mycelia. The type species is Nonomuraea pusilla. At the time of writing, the genus Nonomuraea comprised 27 species and two subspecies with validly published names (http:// www.bacterio.cict.fr/index.html), which were established on the basis of a polyphasic approach (Gyobu \& Miyadoh, 2001; Stackebrandt et al., 2001; Quintana et al., 2003; Ara et al., 2007a, b; Le Roes \& Meyers, 2008; Kämpfer et al., 2010; Wang et al., 2011; Zhao et al., 2011; Xi et al., 2011).

Strain FXJ1.102 ${ }^{\mathrm{T}}$ was isolated from acidic soil $(\mathrm{pH} 5.0)$ collected from Jiangxi Agricultural University, Nanchang city, Jiangxi Province, China. The sample was dried at room temperature, ground into powder and then suspended in sterile distilled water and serially diluted. The diluted soil suspension was incubated on humic acid-vitamin agar (pH 5.0; Hayakawa \& Nonomura, 1987) supplemented with (mg l$~^{-1}$ ) cycloheximide (50), nystatin (50) and nalidixic acid (20) at $28{ }^{\circ} \mathrm{C}$ for 3 weeks. The strain was maintained on

The GenBank/EMBL/DDBJ accession number for the 16S rRNA gene sequence of strain FXJ1.102 ${ }^{\top}$ is FJ418910.

Two supplementary figures are available with the online version of this paper. glucose-yeast extract-malt extract agar [International Streptomyces Project medium 2 (ISP 2), pH 5.0; Shirling \& Gottlieb, 1966] at $4{ }^{\circ} \mathrm{C}$ and as suspensions of mycelial fragments in $20 \%(\mathrm{v} / \mathrm{v})$ glycerol at $-20{ }^{\circ} \mathrm{C}$.

The morphological properties of the isolate were examined by light microscopy (Zeiss Axioskop) and scanning electron microscopy (model FEI Quanta 200) using cultures grown on ISP 2 at $28{ }^{\circ} \mathrm{C}$ for 14 days. For cultural characterization, the isolate was grown at $28{ }^{\circ} \mathrm{C}$ for $14-21$ days on various agar media as described by Waksman (1961) and Shirling \& Gottlieb (1966). Growth at pH 4.0-11.0 (at intervals of one $\mathrm{pH}$ unit) was determined on Bennett's medium at $28{ }^{\circ} \mathrm{C}$ for 14 days. Growth at $4,10,15,20,28$, 37,45 and $55{ }^{\circ} \mathrm{C}$ and with $0-10 \%(w / v) ~ \mathrm{NaCl}$ (at intervals of $1 \%$ ) at $28{ }^{\circ} \mathrm{C}$ was determined on ISP 2 for 14 days. Decomposition of adenine, guanine, arbutin, hypoxanthine, L-tyrosine, xanthine, casein, aesculin, urea and allantoin was evaluated using the media of Gordon et al. (1974). Utilization of various compounds as sole carbon sources was tested using ISP 9 as the basal medium, according to the method of Pridham \& Gottlieb (1948).

Strain FXJ1.102 ${ }^{\mathrm{T}}$ showed good growth on ISP 2, ISP 3, nutrient agar, tryptic soy agar (TSA; Difco, Becton Dickinson) and glucose-asparagine agar, moderate growth on ISP 4, ISP 6 and ISP 7 and poor growth on ISP 5 and Czapek's agar. The isolate produced an ivory to dark yellow substrate mycelium 
on various agar media and a white aerial mycelium that differentiated into spiral spore chains on ISP 2, ISP 3 and ISP 4 (Fig. S1, available in IJSEM Online). No soluble pigments were produced on any of the above media. The physiological and biochemical characteristics that serve to distinguish between strain FXJ1.102 ${ }^{\mathrm{T}}$ and closely related strains of species of the genus Nonomuraea are shown in Table 1.

Biomass for fatty acid analysis was prepared by scraping colonies from TSA plates that had been incubated for 14 days at $28{ }^{\circ} \mathrm{C}$. For other chemotaxonomic analyses, freeze-dried cells were obtained from cultures grown in ISP 2 broth on a rotary shaker at $180-200$ r.p.m. and $28{ }^{\circ} \mathrm{C}$ for 7 days. The isomer of the diaminopimelic acid and whole cell sugars were determined using standard procedures (Lechevalier \& Lechevalier, 1980; Hasegawa et al. 1983). Menaquinones were extracted and purified according to the method of Collins (1985) and analysed by HPLC (Kroppenstedt, 1985). Polar lipids were extracted, examined and identified using the two-dimensional TLC procedure described by Minnikin et al. (1984). Fatty acids were analysed using the standard MIDI procedure (Sherlock version 6.0; Microbial Identification; Sasser, 1990) and a gas chromatograph (Agilent GC 6890). The fatty acids were identified using the database library TSBA6 version 6.0.

Strain FXJ1.102 ${ }^{\mathrm{T}}$ exhibited chemotaxonomic characteristics that are typical for members of the genus Nonomuraea, such as the presence of meso-diaminopimelic acid in the peptidoglycan and galactose, glucose, mannose, ribose and madurose as whole-cell sugars (cell-wall chemotype IIIB) (Lechevalier \& Lechevalier, 1970). The predominant menaquinone was MK-9 $\left(\mathrm{H}_{4}\right)(72.9 \%)$ and minor amounts of MK-9 $\left(\mathrm{H}_{6}\right)(12.2 \%)$, MK-9 $\left(\mathrm{H}_{2}\right)(10.7 \%)$ and MK-9 $(4.2 \%)$ were also present. The detected phospholipids were diphosphatidylglycerol, phosphatidylmethylethanolamine, phosphatidylethanolamine, hydroxy-phosphatidylmethylethanolamine, two unknown glucosamine-containing phospholipids, phosphatidylinositol, phosphatidylglycerol and an unknown phospholipid (Fig. S2), which corresponds to phospholipid type IV (Lechevalier et al., 1977). The detailed fatty acid composition was iso- $\mathrm{C}_{16: 0}(22.2 \%)$, iso- $\mathrm{C}_{16: 1} \mathrm{G}$ (20.4\%), $\mathrm{C}_{17: 1} \omega 6 c(16.6 \%), 10$-methyl $\mathrm{C}_{17: 0}(7.8 \%)$, iso$\mathrm{C}_{15: 0}(7.3 \%)$, anteiso- $\mathrm{C}_{17: 0}(4.0 \%), 10$-methyl $\mathrm{C}_{16: 0}(3.6 \%)$, 10-methyl $\mathrm{C}_{19: 0}$ (2.9\%), $\mathrm{C}_{16: 1} \omega 7 c(2.6 \%), \mathrm{C}_{14: 0}(2.0 \%)$, $\mathrm{C}_{17: 1} \omega 8 c(1.9 \%), \mathrm{C}_{16: 0}(1.6 \%)$, iso- $\mathrm{C}_{14: 0}(1.5 \%), \mathrm{C}_{18: 0}$ $(0.9 \%), \mathrm{C}_{15: 0} 2-\mathrm{OH}(0.9 \%), \mathrm{C}_{16: 0} 2-\mathrm{OH}(0.8 \%), \mathrm{C}_{17: 0}$ $(0.6 \%)$, iso- $\mathrm{C}_{15: 0} \mathrm{G}(0.6 \%), \mathrm{C}_{13: 0}(0.5 \%)$, iso- $\mathrm{C}_{17: 0}(0.4 \%)$, 10-methyl $\mathrm{C}_{18: 0}(0.4 \%), \mathrm{C}_{12: 0}(0.2 \%)$, anteiso- $\mathrm{C}_{15: 0}(0.2 \%)$, iso- $\mathrm{C}_{18: 0}(0.1 \%)$, anteiso- $\mathrm{C}_{17: 1} \omega 9 c(0.1 \%)$ and $\mathrm{C}_{18: 1} \omega 9 c$ $(0.1 \%)$.

Extraction of genomic DNA and amplification and sequencing of the 16S rRNA gene were carried out using the method of Ara \& Kudo (2006). An almost full-length $16 \mathrm{~S}$ rRNA gene sequence (1486 bp) was aligned with related sequences obtained from public databases using CLUSTAL $\mathrm{X}$ version 1.8 (Thompson et al., 1997) and the calculation of pairwise 16S rRNA gene sequence similarities was achieved using the EzTaxon server (http://www.eztaxon.org/; Chun et al., 2007). Neighbour-joining (Saitou \& Nei, 1987) and maximum-parsimony (Fitch, 1971) trees were constructed using MEGA version 4.0 (Tamura et al., 2007). The reliability

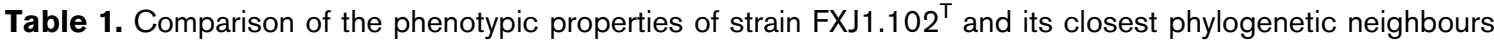

Strains: 1, Nonomuraea jiangxiensis sp. nov. FXJ1.102 $2^{\mathrm{T}}$; 2, N. candida HMC10 ${ }^{\mathrm{T}}$; 3, N. antimicrobica YIM 61105 $5^{\mathrm{T}}$; 4, 'N. aegyptia' S136; 5, N. turkmeniaca DSM $43926^{\mathrm{T}} ; 6$, N. rubra JCM $3389^{\mathrm{T}}$. All data were taken from this study. +, Positive; w, weakly positive; - , negative.

\begin{tabular}{|c|c|c|c|c|c|c|}
\hline Characteristic & 1 & 2 & 3 & 4 & 5 & 6 \\
\hline Nitrate reductase & + & - & - & - & + & + \\
\hline \multicolumn{7}{|l|}{ Degradation of: } \\
\hline Gelatin & - & $\mathrm{W}$ & - & - & + & + \\
\hline Aesculin & + & + & - & - & - & + \\
\hline Casein & + & + & + & - & + & - \\
\hline L-Tyrosine & $\mathrm{w}$ & - & - & - & - & + \\
\hline Adenine & - & + & - & - & + & + \\
\hline Guanine & $\mathrm{w}$ & $\mathrm{w}$ & - & - & $\mathrm{w}$ & - \\
\hline Hypoxanthine & - & - & - & - & + & + \\
\hline \multicolumn{7}{|l|}{ Utilization as sole carbon source: } \\
\hline L-Arabinose & + & $\mathrm{w}$ & - & + & + & + \\
\hline meso-Erythritol & - & - & + & $\mathrm{w}$ & - & - \\
\hline myo-Inositol & - & + & - & + & + & + \\
\hline Cellobiose & + & $\mathrm{w}$ & - & + & + & + \\
\hline Sucrose & - & + & + & + & + & + \\
\hline Xylose & - & + & - & + & + & + \\
\hline Ribose & - & + & + & - & - & - \\
\hline Maximum $\mathrm{NaCl}$ concentration for growth $(\%, w / v)$ & 6 & 5 & 5 & 6 & 7 & 6 \\
\hline Temperature for growth $\left({ }^{\circ} \mathrm{C}\right)$ & $20-45$ & $15-45$ & $15-37$ & $15-37$ & $10-37$ & $10-45$ \\
\hline
\end{tabular}




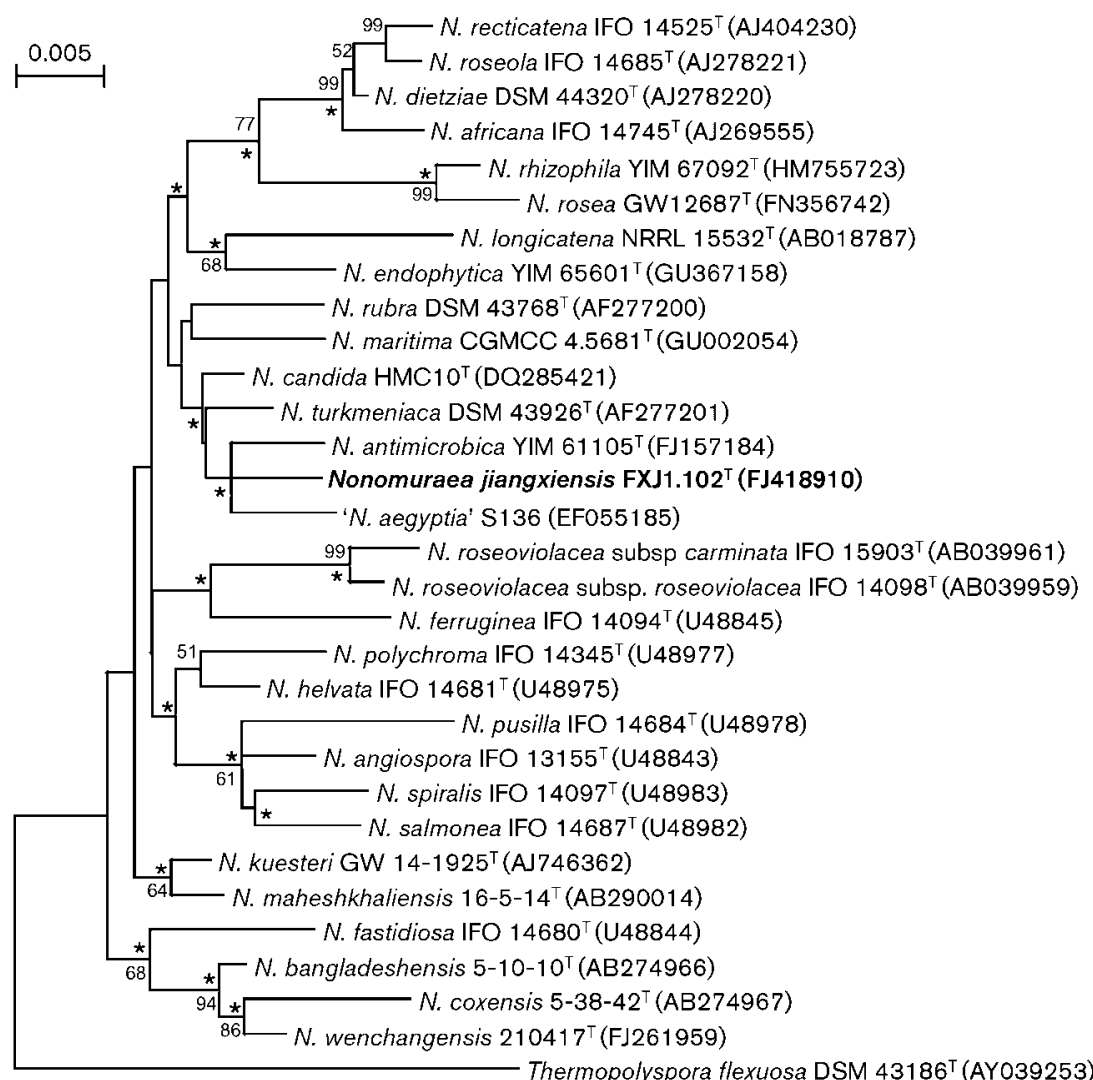

Fig. 1. Neighbour-joining tree based on nearly complete $16 \mathrm{~S}$ rRNA gene sequences ( $>1376$ bp, without gaps) showing the relationships between strain FXJ1.102 ${ }^{\top}$ and the type strains of recognized species of the genus Nonomuraea. Bootstrap values (>50\%) based on 1000 resampled datasets are given at branch nodes. Asterisks indicated that the corresponding nodes were also recovered using the maximum-parsimony method. Bar, 0.005 substitutions per nucleotide position. of the tree topology was evaluated by bootstrap analysis (Felsenstein, 1985).

Phylogenetic analysis based on 16S rRNA gene sequences revealed that strain FXJ1.102 ${ }^{\mathrm{T}}$ belonged to the genus Nonomuraea. The isolate formed a subcluster with Nonomuraea antimicrobica YIM $61105^{\mathrm{T}}$ and 'Nonomuraea aegyptia' S136, recovered by both the neighbour-joining and the maximum-parsimony algorithms (Fig. 1), with which it shared 97.9 and $97.5 \% 16 \mathrm{~S}$ rRNA gene sequence similarity, respectively. The isolate also shared high $16 \mathrm{~S}$ rRNA gene sequence similarity with other members of the cluster to which the subcluster belonged (Nonomuraea candida HMC10 ${ }^{\mathrm{T}}$, 98.9\%; Nonomuraea turkmeniaca DSM $43926^{\mathrm{T}}$, $98.3 \%$; Nonomuraea rubra DSM $43768^{\mathrm{T}}, 98.0 \%$ ) and a relatively distant cluster (Nonomuraea kuesteri GW $14-1925^{\mathrm{T}}$, $98.5 \%$; Nonomuraea maheshkhaliensis $16-5-14^{\mathrm{T}}$, 98.1\%).

The DNA G $+\mathrm{C}$ content of strain FXJ1.102 ${ }^{\mathrm{T}}$ was determined by HPLC and found to be $72.6 \mathrm{~mol} \%$ (Tamaoka \& Komagata, 1984). Using the method described by Rong \& Huang (2010), DNA-DNA hybridization was carried out between the isolate and the type strains that were most closely related in terms of both $16 \mathrm{~S}$ rRNA gene sequence similarity or phylogenetic position, i.e. N. candida DSM $45086^{\mathrm{T}}, N$. turkmeniaca DSM 43926 ${ }^{\mathrm{T}}$, N. antimicrobica YIM $61105^{\mathrm{T}}$ and ' $N$. aegyptia' S136. Strain FXJ1.102 showed low DNA-DNA relatedness with the reference strains $(22.4 \pm 4.2,21.0 \pm 4.0,19.4 \pm 2.2$ and $16.0 \pm 2.6 \%$, respectively). These values are well below the $70 \%$ cut-off point for assigning strains to the same species (Stackebrandt \& Goebel, 1994). Previous studies have shown that members of the genus Nonomuraea that exhibit high 16S rRNA gene sequence similarity (ranging from 97.6 to $99.4 \%$ ) can exhibit low DNA-DNA relatedness (Fischer et al., 1983; Poschner et al., 1985; Stackebrandt et al. 2001; Kämpfer et al., 2005); therefore, DNA-DNA hybridizations were not carried out between strain FXJ1.102 ${ }^{\mathrm{T}}$ and other members of the genus Nonomuraea.

The morphological, chemotaxonomic and phylogenetic data clearly support the assignment of strain FXJ1.102 ${ }^{\mathrm{T}}$ to the genus Nonomuraea, but the physiological characters and DNA-DNA relatedness demonstrate that the strain can be differentiated from its closest relatives in the genus Nonomuraea. Therefore, on the basis of genotypic and phenotypic evidence, strain FXJ1.102 ${ }^{\mathrm{T}}$ represents a novel species of the genus Nonomuraea, for which the name Nonomuraea jiangxiensis sp. nov. is proposed.

\section{Description of Nonomuraea jiangxiensis sp. nov.}

Nonomuraea jiangxiensis (ji.ang.xi.en'sis. N.L. fem. adj. jiangxiensis of or belonging to Jiangxi Province, south-east China, the source of the type strain).

Substrate mycelium is ivory on ISP 3 and Czapek's agar, dark yellow on ISP 2 and yellow on ISP 4, ISP 5, ISP 6, ISP 
7, TSA, nutrient agar and glucose-asparagine agar. White aerial mycelium is produced on ISP 2, ISP 3 and ISP 4. No soluble pigments are produced on any of the above media. The micromorphological characteristics are typical for the genus Nonomuraea. Casein, aesculin, allantoin and arbutin are hydrolysed and L-tyrosine and guanine are weakly hydrolysed, but adenine, hypoxanthine, gelatin, starch, xanthine and urea are not hydrolysed. Catalase-positive. Nitrate is reduced. $\mathrm{H}_{2} \mathrm{~S}$ is not produced. Utilizes Larabinose, cellobiose, dextrin, D-galactose, D-glucose, glycerol, lactose, maltose, mannitol, D-mannose, melibiose, raffinose, rhamnose, salicin, adonitol and methyl $\alpha$-Dglucoside as sole carbon sources, but not myo-inositol, sucrose, xylose, ribose, D-fructose, trehalose, D-sorbitol or meso-erythritol. Grows with up to $6 \%(\mathrm{w} / \mathrm{v}) \mathrm{NaCl}$ (optimum $0 \% \mathrm{NaCl}$ ), at $\mathrm{pH}$ 5.0-9.0 (optimum $\mathrm{pH} 6.0$ ) and at $20-45{ }^{\circ} \mathrm{C}$ (optimum $25-35{ }^{\circ} \mathrm{C}$ ). The diagnostic diamino acid of the peptidoglycan is meso-diaminopimelic acid. Cell hydrolysates contain madurose, glucose, mannose, ribose and galactose. The polar lipids include diphosphatidylglycerol, phosphatidylmethylethanolamine, phosphatidylethanolamine, hydroxy-phosphatidylmethylethanolamine, two unknown glucosamine-containing phospholipids, phosphatidylinositol, phosphatidylglycerol and an unknown phospholipid. The predominant menaquinone of the type strain is MK-9 $\left(\mathrm{H}_{4}\right)$. The major fatty acids $(>10 \%)$ are iso- $\mathrm{C}_{16: 0}$, iso- $\mathrm{C}_{16: 1} \mathrm{G}$ and $\mathrm{C}_{17: 1} \omega 6 c$.

The type strain, FXJ1.102 ${ }^{\mathrm{T}}\left(=\mathrm{CGMCC} 4.6533^{\mathrm{T}}=\mathrm{NBRC}\right.$ $106679^{\mathrm{T}}$ ), was isolated from acidic soil in Nanchang city, Jiangxi Province, China. The DNA G $+\mathrm{C}$ content of the type strain is $72.6 \mathrm{~mol} \%$.

\section{Acknowledgements}

We thank the international culture collections CGMCC and JCM for providing type strains. This research was supported by the National Natural Science Foundation of China (grant no. 31170010) and the Opening Project of the State Key Laboratory of Microbial Resources.

\section{References}

Ara, I. \& Kudo, T. (2006). Three novel species of the genus Catellatospora, Catellatospora chokoriensis sp. nov., Catellatospora coxensis sp. nov. and Catellatospora bangladeshensis sp. nov., and transfer of Catellatospora citrea subsp. methionotrophica Asano and Kawamoto 1988 to Catellatospora methionotrophica sp. nov., comb. nov. Int J Syst Evol Microbiol 56, 393-400.

Ara, I., Kudo, T., Matsumoto, A., Takahashi, Y. \& Omura, S. (2007a). Nonomuraea maheshkhaliensis sp. nov., a novel actinomycete isolated from mangrove rhizosphere mud. J Gen Appl Microbiol 53, 159-166.

Ara, I., Kudo, T., Matsumoto, A., Takahashi, Y. \& Omura, S. (2007b). Nonomuraea bangladeshensis sp. nov. and Nonomuraea coxensis sp. nov. Int J Syst Evol Microbiol 57, 1504-1509.

Chiba, S., Suzuki, M. \& Ando, K. (1999). Taxonomic re-evaluation of 'Nocardiopsis' sp. K-252 ${ }^{\mathrm{T}}$ (=NRRL $15532^{\mathrm{T}}$ ): a proposal to transfer this strain to the genus Nonomuraea as Nonomuraea longicatena sp. nov. Int J Syst Bacteriol 49, 1623-1630.
Chun, J., Lee, J.-H., Jung, Y., Kim, M., Kim, S., Kim, B. K. \& Lim, Y.-W. (2007). EzTaxon: a web-based tool for the identification of prokaryotes based on $16 \mathrm{~S}$ ribosomal RNA gene sequences. Int J Syst Evol Microbiol 57, 2259-2261.

Collins, M. D. (1985). Isoprenoid quinone analysis in classification and identification. In Chemical Methods in Bacterial Systematics, pp. 267-287. Edited by M. Goodfellow \& D. E. Minnikin. London: Academic Press.

Felsenstein, J. (1985). Confidence limits on phylogenies: an approach using the bootstrap. Evolution 39, 783-789.

Fischer, A., Kroppenstedt, R. M. \& Stackebrandt, E. (1983). Molecular-genetic and chemotaxonomic studies on Actinomadura and Nocardiopsis. J Gen Microbiol 129, 3433-3446.

Fitch, W. M. (1971). Toward defining the course of evolution: minimum change for a specific tree topology. Syst Zool 20, 406-416.

Gordon, R. E., Barnett, D. A., Handerhan, J. E. \& Pang, C. H.-N. (1974). Nocardia coeliaca, Nocardia autotrophica, and the nocardin strain. Int J Syst Bacteriol 24, 54-63.

Gyobu, Y. \& Miyadoh, S. (2001). Proposal to transfer Actinomadura carminata to a new subspecies of the genus Nonomuraea as Nonomuraea roseoviolacea subsp. carminata comb. nov. Int J Syst Evol Microbiol 51, 881-889.

Hasegawa, T., Takizawa, M. \& Tanida, S. (1983). A rapid analysis for chemical grouping of aerobic actinomycetes. J Gen Microbiol 29, 319-322.

Hayakawa, M. \& Nonomura, H. (1987). Humic acid-vitamin agar, a new medium for selective isolation of soil actinomycetes. $J$ Ferment Technol 65, 501-509.

Kämpfer, P., Kroppenstedt, R. M. \& Grün-Wollny, I. (2005). Nonomuraea kuesteri sp. nov. Int J Syst Evol Microbiol 55, 847-851.

Kämpfer, P., Busse, H. J., Tindall, B. J., Nimtz, M. \& Grün-Wollny, I. (2010). Nonomuraea rosea sp. nov. Int J Syst Evol Microbiol 60, 11181124.

Kroppenstedt, R. M. (1985). Fatty acid and menaquinone analysis of actinomycetes and related organisms. In Chemical Methods in Bacterial Systematics (Society for Applied Bacteriology Technical Series vol. 20), pp. 173-199. Edited by M. Goodfellow \& D. E. Minnikin. New York: Academic Press.

Le Roes, M. \& Meyers, P. R. (2008). Nonomuraea candida sp. nov., a new species from South African soil. Antonie van Leeuwenhoek 93, 133-139.

Lechevalier, M. P. \& Lechevalier, H. A. (1970). Chemical composition as a criterion in the classification of aerobic actinomycetes. Int J Syst Bacteriol 20, 435-443.

Lechevalier, M. P. \& Lechevalier, H. A. (1980). The chemotaxonomy of actinomycetes. In Actinomycete Taxonomy (Special Publication no. 6), pp. 227-291. Edited by A. Dietz \& J. Thayer. Arlington, VA: Society for Industrial Microbiology.

Lechevalier, M. P., De Bièvre, C. \& Lechevalier, H. A. (1977). Chemotaxonomy of aerobic actinomycetes: phospholipid composition. Biochem Syst Ecol 5, 249-260.

Minnikin, D. E., O'Donnell, A. G., Goodfellow, M., Alderson, G., Athalye, M., Schaal, K. \& Parlett, J. H. (1984). An integrated procedure for the extraction of bacterial isoprenoid quinones and polar lipids. J Microbiol Methods 2, 233-241.

Poschner, J., Kroppenstedt, R. M., Fischer, A. \& Stackebrandt, E. (1985). DNA-DNA reassociation and chemotaxonomic studies on Actinomadura, Microbispora, Microtetraspora, Micropolyspora and Nocardiopsis. Syst Appl Microbiol 6, 264-270.

Pridham, T. G. \& Gottlieb, D. (1948). The utilization of carbon compounds by some Actinomycetales as an aid for species determination. J Bacteriol 56, 107-114. 
Quintana, E., Maldonado, L. \& Goodfellow, M. (2003). Nonomuraea terrinata sp. nov., a novel soil actinomycete. Antonie van Leeuwenhoek 84, 1-6.

Rong, X. \& Huang, Y. (2010). Taxonomic evaluation of the Streptomyces griseus clade using multilocus sequence analysis and DNA-DNA hybridization, with proposal to combine 29 species and three subspecies as 11 genomic species. Int J Syst Evol Microbiol 60, 696-703.

Saitou, N. \& Nei, M. (1987). The neighbor-joining method: a new method for reconstructing phylogenetic trees. Mol Biol Evol 4, 406-425.

Sasser, M. (1990). Identification of bacteria by gas chromatography of cellular fatty acids, MIDI Technical Note 101. Newark, DE: MIDI Inc.

Shirling, E. B. \& Gottlieb, D. (1966). Methods for characterization of Streptomyces species. Int J Syst Bacteriol 16, 313-340.

Stackebrandt, E. \& Goebel, B. M. (1994). Taxonomic note: a place for DNA-DNA reassociation and $16 \mathrm{~S}$ rRNA sequence analysis in the present species definition in bacteriology. Int J Syst Bacteriol 44, 846-849.

Stackebrandt, E., Wink, J., Steiner, U. \& Kroppenstedt, R. M. (2001). Nonomuraea dietzii sp. nov. Int J Syst Evol Microbiol 51, 1437-1441.

Tamaoka, J. \& Komagata, K. (1984). Determination of DNA base composition by reversed-phase high-performance liquid chromatography. FEMS Microbiol Lett 25, 125-128.
Tamura, K., Dudley, J., Nei, M. \& Kumar, S. (2007). MEGA4: molecular evolutionary genetics analysis (MEGA) software version 4.0. Mol Biol Evol 24, 1596-1599.

Thompson, J. D., Gibson, T. J., Plewniak, F., Jeanmougin, F. \& Higgins, D. G. (1997). The CLUSTAL_X windows interface: flexible strategies for multiple sequence alignment aided by quality analysis tools. Nucleic Acids Res 25, 4876-4882.

Waksman, S. A. (1961). The Actinomycetes, vol. 2. Baltimore: Williams \& Wilkins.

Wang, F., Xu, X.-X., Qu, Z., Wang, C., Lin, H.-P., Xie, Q.-Y., Ruan, J.-S., Sun, M. \& Hong, K. (2011). Nonomuraea wenchangensis sp. nov., isolated from mangrove rhizosphere soil. Int J Syst Evol Microbiol 61, 1304-1308.

Xi, L., Zhang, L., Ruan, J. \& Huang, Y. (2011). Nonomuraea maritima sp. nov., isolated from coastal sediment. Int J Syst Evol Microbiol 61, 2740-2744.

Zhang, Z., Wang, Y. \& Ruan, J. (1998). Reclassification of Thermomonospora and Microtetraspora. Int J Syst Bacteriol 48, 411-422.

Zhao, G.-Z., Li, J., Huang, H.-Y., Zhu, W.-Y., Xu, L.-H. \& Li, W.-J. (2011). Nonomuraea rhizophila sp. nov., an actinomycete isolated from rhizosphere soil. Int J Syst Evol Microbiol 61, 2141-2145. 